\title{
Comparison of sapwood invasion by three Phytophthora spp. in different hosts
}

\author{
E. M. Davison ${ }^{1}$, E. J. Speijers ${ }^{2}$, F. C. S. Tay ${ }^{1}$ \\ ${ }^{1}$ Department of Environment and Agriculture, Curtin University, GPO Box U1987, Perth, WA 6845, \\ Australia \\ ${ }^{2}$ MCSP, 11A Swanbourne St, Fremantle, WA 6160, Australia
}

\begin{abstract}
Many Phytophthora spp. have recently been isolated from native vegetation in Western Australia. As their pathogenicity is often unknown, it is not possible to provide advice to land managers on the impact of site infestation on native plants and how these infestations should be managed. We describe a rapid screening method based on sapwood invasion that has been used to compare the pathogenicity of Phytophthora arenaria, P. cinnamomi and P. multivora. Radial invasion into the xylem of six banksias and three eucalypts was assessed in an excised branch assay in summer and winter. Branches were wound inoculated and invasion was assessed by plating from a strip of tissue cut across the stem at the inoculation point and at $40 \mathrm{~mm}$ above and below. A symptomless infection had established in both the bark and sapwood within 6 days. P. arenaria was only isolated from the strip of tissue at the inoculation point. $P$. cinnamomi was isolated from the sapwood of $B$. attenuata, $B$. burdettii, $B$. menziesii and $B$. speciosa $40 \mathrm{~mm}$ above or below the inoculation point in some experiments. P. multivora was isolated from $B$. speciosa $40 \mathrm{~mm}$ below the inoculation point in one experiment. Hyphae of both species were seen in both ray parenchyma cells and xylem vessels. The invasiveness of the Phytophthora spp. was compared on the two groups of hosts using scores for sapwood invasion at the inoculation point. For banksias, $P$. cinnamomi and $P$. multivora had significantly higher invasion scores on banksias than $P$. arenaria but were not significantly different to one another. There was no significant difference between the three Phytophthora spp. on the eucalypt hosts. Assessing sapwood invasion provides a rapid, inexpensive and biologically meaningful way of screening the many Phytophthora spp. that have been isolated from native vegetation.
\end{abstract}

Keywords methods, inapparent infection, pathogenicity

\section{Introduction}

The jarrah forest, coastal heathlands and sandplains of the southwest of Western Australia (WA) are areas of exceptionally high botanical diversity. The conservation value of these areas is significantly reduced by the introduced soilborne pathogen Phytophthora cinnamomi which is associated with the death of many woody native plants (Podger 1972; Wills 1992; McDougall et al. 2002; Cahill et al. 2008; Shearer et al. 2009; Shearer et al. 2012). Banksia spp. are particularly susceptible and infested areas are often clearly delimited by their sudden death. Two of the most effective tools for managing the spread of $P$. cinnamomi are exclusion and hygiene, both of which depend on being 
able to accurately map the pathogen's distribution. This is achieved through vegetation surveys together with laboratory assays of soil and plant material (CALM 2003).

Phytophthora cinnamomi is not the only Phytophthora spp. that occurs in native vegetation in WA. Molecular sequencing has shown that there are many previously unrecognised species that can be isolated from recently dead plants, soil and water bodies (Burgess et al. 2009; Jung et al. 2011; Hüberli et al. 2013). Areas infested by these species cannot be demarcated in the same way as those infested by $P$. cinnamomi because their presence is not necessarily associated with patches of dead native plants. As the pathogenic status of many of these species is not known, plant pathologists are unable to provide robust advice to land managers as to the implications of site infestation and how such sites should be managed. What is needed is an inexpensive, reproducible, biologically meaningful screening method for assessing the pathogenicity of different species.

Pathogenicity testing of soilborne Phytophthora spp. has been done in many ways and all have advantages and limitations, as indicated below.

Monitoring the survival of seedlings planted on infested sites is inexpensive, but is long term. It may also be confounded by the heterogeneity of the site, weather conditions and the possibility that surviving plants are disease escapes (McCreadie et al. 1985; Stukely and Crane 1994).

Glasshouse experiments are frequently used to assess pathogenicity. These are quicker, but are expensive in terms of facilities and labour and results may be confounded if soil temperature and moisture are not rigorously controlled (Passioura 2012). Pots are often regularly flooded to stimulate the formation of sporangia (Gisi et al. 1980), enable zoospore discharge (MacDonald and Duniway 1978), facilitate zoospore movement (Newhook et al. 1981) and promote root infection (Davison and Tay 1987), with cycles of infection being set up by repeated flooding and draining. However hypoxia and anoxia that result from flooding soil for a few hours also affect root tips, resulting in anaerobic respiration, reduced cell division, reduced root elongation, reduced water uptake and root death (Drew 1997). Thus the effects of infection may be confounded by the sensitivity of the host plant to flooding.

Another type of pathogenicity testing that is widely used for woody plants is wound inoculations. These can be performed in the field (Tippett et al. 1983; Bunny et al. 1995), on glasshouse grown plants (Stukely and Crane 1994), or on excised organs in the laboratory (Tynan et al. 1998). When a stem or root is wound inoculated with $P$. cinnamomi a necrotic lesion is formed in the phloem which is revealed once the periderm is removed. P. cinnamomi however is a hemibiotroph, so that colonisation is greater than the size of the visible lesion (Hüberli et al. 2002). Shearer and Crane (2012) however, concluded that determining the extent of colonisation, compared with the size of necrotic lesions, was more expensive and time consuming, and added little additional information when comparing susceptibility of different host species.

When P. cinnamomi is wound inoculated into woody stems and roots it rapidly forms a symptomless infection in both the phloem and sapwood (Davison et al. 1994; Davison 2011). Sapwood invasion varies between hosts, for example in summer it is more extensive in Banksia grandis than in Eucalyptus marginata. It may also provide a way to compare the pathogenicity of different Phytophthora spp. Specifically we have compared radial invasion of the sapwood in excised stems of eucalypts and banksias by three Phytophthora spp. that occur in the southwest of WA and are likely 
to have a range of pathogenicity. We have used $P$. multivora (Scott et al. 2009) (which was previously misidentified as $P$. citricola), and $P$. arenaria (Rea et al. 2011), in comparison with $P$. cinnamomi. P. multivora is widespread and has been frequently isolated from dying native plants. $P$. arenaria has a more restricted distribution than $P$. cinnamomi and $P$. multivora, and was less pathogenic in glasshouse experiments.

\section{Methods}

Isolates and production of inoculum

Details of the isolates of Phytophthora spp. used in these experiments are given in Table 1. All isolates were identified by Crop Health Services, Agriculture Victoria, Knoxfield, Victoria. The identification was by comparing ITS sequences with sequences on GenBank.

The inoculum was a sterile $5 \mathrm{~mm}$ Miracloth (Chickopee Mills, NY) disc which was place on pea agar (200 g macerated frozen peas, $15 \mathrm{~g}$ agar, $1 \mathrm{~L}$ de-ionised water) culture, adjacent to the margin of the developing colony. Plates were incubated at room temperature $\left(21^{\circ} \mathrm{C}+/-1^{\circ} \mathrm{C}\right)$, under daylight conditions for 6 days, and the colonised discs were removed aseptically and used immediately.

Plant material and inoculation procedure

Nine host species were each inoculated on a winter date and a summer date (Table 2). Branches were cut the day before they were required and, for each species, all branches came from the same plant. The branches (mean diameter $24.8 \mathrm{~mm}$, SD $4.6 \mathrm{~mm}$ ) were cut to about $20-25 \mathrm{~cm}$ length, the leaves removed, and the ends sealed with molten candle wax. They were stored in a polythene bag at room temperature overnight.

The following day the inoculation point was marked with a permanent marker pen, and a $5 \mathrm{~mm}$ diameter piece of the outer bark cut with a sterile cork-borer, and removed with a sterile scalpel and sterile forceps. The inoculum disc was place on the exposed inner bark, covered with the piece of outer bark, and sealed with petroleum jelly. There were five replicate branches for each Phytophthora spp. used. Inoculated branches were place in plastic tubs, each tub enclosed in a sealed polythene bag, and incubated in diffuse light at room temperature $\left(21^{\circ} \mathrm{C}+/-1^{\circ} \mathrm{C}\right)$ for 6 days.

\section{Harvesting}

At harvest the petroleum jelly was removed from the inoculation point and the inoculum disc plated on Phytophthora-selective agar (17 g corn meal agar, $100 \mathrm{mg}$ ampicillin, $50 \mathrm{~g}$ hymexazol, $100 \mathrm{mg}$ PCNB, $1 \mathrm{ml}$ nystatin, $0.5 \mathrm{ml}$ rifadin, $1 \mathrm{~L}$ de-ionised water). A point $40 \mathrm{~mm}$ above and $40 \mathrm{~mm}$ below the inoculation point was marked on each inoculated branch. A band saw was used to cut three strips of wood, $5 \times 5 \mathrm{~mm}$ in cross section through the diameter of the branch at the inoculation point and $40 \mathrm{~mm}$ above and below. This strip of bark and wood was cut into the following pieces with a sterile scalpel: outer bark, inner bark, 0-5 mm sapwood, 5-10 mm sapwood, 10-15 mm sapwood. Each piece was plated onto Phytophthora-selective agar without surface sterilization. The plates were incubated at room temperature and examined after 2, 5 and 7 days for growth of Phytophthora spp. 
Growth rate on agar

Radial growth on corn meal agar ( $17 \mathrm{~g}$ corn meal agar, $1 \mathrm{~L}$ de-ionised water) from $5 \mathrm{~mm}$ diameter Miracloth discs was measured at $21^{\circ} \mathrm{C}$. The inoculum disc was placed on one side of the plate and colony radius measured after 6 days. There were five replicate plates in each experiment which was conducted twice.

Histology

At harvest, a block of wood, approximately $30 \mathrm{~mm}$ long, immediately above the inoculation point from each replicate was marked with the replicate number and position of the inoculation, and then fixed in $50 \%$ ethanol. Only replicates from which Phytophthora spp. had been isolated from the wood were used to determine where hyphae were present. Transverse and radial longitudinal sections ( $40 \mu \mathrm{m}$ thick) were cut through the wood immediately adjacent to the inoculation point using a sledge microtome (American Optical Corp., Buffalo, NY). The sections were stained with iodine solution and mounted in glycerol. Immediately before examination the sections were leached with water, stained with lactofuchsin, and mounted in lactic acid and examined for the presence of hyphae.

Statistical analysis

Invasion score represents how far the pathogen invaded the sapwood on a scale of 0-3 and has been defined as: 0 not present in the sapwood; 1 present $0-5 \mathrm{~mm}$ into the sapwood; 2 present $5-10 \mathrm{~mm}$ into the sapwood; 3 present $10-15 \mathrm{~mm}$ into the sapwood.

Analyses were conducted using GenStat for Windows 15th Edition (VSN International 2012). An analysis of variance was carried out to examine the effects of Host, Pathogen and Season on invasion score. The effect of host was subdivided into a comparison between Banksia and Eucalypt hosts (Banksia vs Eucalypt), the difference between Banksia hosts (BanksiaHost) and the difference between Eucalypt hosts (EucalyptHost).

A further analysis was undertaken to assess the invasiveness of pathogens with respect to Banksia and Eucalypt species. A linear mixed model was fitted to the invasion scores in which BanksiaHost and EucalyptHost and interactions with pathogen and time of year were random effects. The fixed model included terms for Banksia vs Eucalypts, pathogen, time of year and all interactions. Residual plots were examined to ensure that statistical tests complied with assumptions of normality and homogeneity of variance.

\section{Results}

Invasion

Phytophthora spp. were recovered from $98.1 \%$ of the inoculum discs after 6 days.

There were no symptoms in the sapwood after 6 days, however some of the inoculations showed slight browning symptoms in the phloem at the inoculation point. Isolations from both the bark and sapwood showed that Phytophthora spp. could be isolated from symptomless tissue. Most of these 
isolations were from the strip of tissue taken at the inoculation point. However in some replicates $P$. cinnamomi was also isolated from the sapwood of $B$. attenuata, B. burdettii, B. menziesii and $B$. speciosa $40 \mathrm{~mm}$ above or below the inoculation in summer, and from B. speciosa $40 \mathrm{~mm}$ above or below the inoculation in winter. P. multivora was isolated from $B$. speciosa $40 \mathrm{~mm}$ below the inoculation in winter. P. arenaria was only isolated from the strip of tissue at the inoculation point. As almost no invasion had taken place $40 \mathrm{~mm}$ from the inoculation point no analysis was performed on data from these positions.

Average invasion scores at the inoculum point are shown in Figure 1. Analysis of invasion scores showed that they were significantly affected by pathogen, host and season, and that not all pathogens and hosts responded in the same way to season (Table 3 ). There was a significant interaction between Pathogen, Season and BanksiaHost $(P<0.001)$ which indicated that the difference between seasons changed with Banksia spp. and pathogen. For $P$. multivora there is invasion score for $B$. ashbyi was higher in summer than in winter, but for $B$. lemanniana the invasion score was lower in summer than in winter. However, for $P$. cinnamomi, there is a higher invasion score in summer than in winter for $B$. lemanniana and $B$. menziesii, and lower invasion score in summer than in winter for $B$. burdettii. Levels of invasion in winter for $P$. arenaria were very low for all Banksia spp. apart from $B$. speciosa, with values significantly lower than in summer for $B$. ashbyi and $B$. burdettii. There was a significant interaction between Pathogen and BanksiaHost $(P=0.001)$ with $B$. speciosa having the highest invasion scores for all pathogens, but other species, such as $B$. attenuata having inconsistent invasions scores with the different pathogens. There was a significant interaction between Pathogen and EucalyptHost $(P=0.028)$ because $P$. cinnamomi and $P$. multivora had their highest invasions scores for $E$. erythrocorys whilst $P$. arenaria had its highest invasion score for E. oleosa.

When the invasiveness of the three Phytophthora spp. was compared on the two groups of hosts there was a significant Pathogen by Banksia vs Eucalypt interaction $(P=0.007$; Table 4). For banksias, P. cinnamomi and P. multivora had significantly higher invasion scores than $P$. arenaria but were not significantly different to one another. There was no significant difference between the three Phytophthora spp. on the eucalypt hosts.

Growth rate on agar

Radial extension on CMA after 6 days was $8.5 \mathrm{~mm}, 50.5 \mathrm{~mm}$ and $28.2 \mathrm{~mm}$ for $P$. arenaria, $P$. cinnamomi and $P$. multivora respectively.

Histology

Sections were only cut from blocks adjacent to sapwood from which the pathogens had been recovered. $P$. arenaria hyphae were seen in the cambium of $B$. speciosa and in a xylem vessel of $B$. burdettii. $P$. cinnamomi hyphae were seen in ray cells of $B$. ashbyi, $B$. burdettii, $B$. lemanniana and $B$. speciosa (Fig. 2A) and xylem vessels of B. attenuata (Fig. 2B), B. burdettii, B. menziesii and $B$. speciosa. P. multivora hyphae were seen in ray cells of $B$. burdettii, B. menziesii and B. speciosa and in xylem vessels of $B$. menziesii and B. speciosa (Fig. 2C).

\section{Discussion}


The aim of this work was to develop a quick, inexpensive, reproducible, biologically meaningful screening method for comparing the pathogenicity of Phytophthora spp. isolated from natural ecosystems. Was this achieved?

This method is quick, with each experiment taking 3 weeks. It is inexpensive, because it uses excised branches, standard laboratory facilities, with a band saw being the only expensive piece of equipment required. The time taken for each experiment is about 15 hours. Its reproducibility was tested by collecting branches from the same plant in two seasons and then incubating the inoculated branches under similar conditions. This showed that not all pathogens and hosts responded the same way in summer and winter (Table 3, Fig. 1). This must indicate that these seasonal differences result from differences in host physiology because all other parameters were kept constant.

Consequently it may not be possible to compare the results of inoculations on branches collected at different times of year without first checking whether or not there are seasonal effects. Lastly, the assessment of sapwood invasion is more biologically meaningful than measuring the extent of visible lesions in the phloem, because colonisation of the sapwood occurs more quickly than the formation of visible lesions. Sapwood invasion by Phytophthora spp. has been recorded in a number of pathosystems (Davison et al. 1994; Smith et al. 1997; Brown and Brasier 2007; Greslebin and Hansen 2010). Sapwood invasion has the potential to lead to hydraulic failure, wilting and death if it is extensive and results in blocked xylem vessels (Parke et al. 2007; Collins et al. 2009). Sapwood invasion is therefore far more damaging to the plant than colonisation of the bark.

Our results show that radial invasion of the sapwood is greater in banksias than in eucalypts (Fig. 1, Table 3) and that banksias allow better comparison of the invasiveness of different Phytophthora spp. than eucalypts (Table 4). P. arenaria was less invasive than P. cinnamomi and P. multivora on banksias, a result that is consistent with glasshouse experiments on seedlings (Rea et al. 2011). This may be because $P$. arenaria grows more slowly on agar than the other species.

This method could also be used in a number of different ways. It could be used to compare the pathogenicity of a number of isolates of the same Phytophthora species against a number of different hosts. It could also be used to compare the susceptibility of different plants of the same species or between closely related species, however more replicates would be needed than the five used in these experiments. An estimate of the variance between branches of the different banksias has been use to estimate the number of replicates required to have a specified probability of detecting real differences of specified sizes at the $5 \%$ level of significance (Table 5). Such a method could also be used for screening populations for potentially resistant individuals (McCredie et al. 1985; Tynan et al. 1998).

Acknowledgements We thank J. Cunnington and J. Edwards for identification of the isolates, J. Edwards for depositing the sequences in GenBank, and colleagues for access to plant material from their gardens.

\section{References}

Brown AV, Brasier CM (2007) Colonization of tree xylem by Phytophthora ramorum, P. kernoviae and other Phytophthora species. Plant Pathol 56: 227-241 
Bunny FJ, Crombie DS, Williams MR (1995) Growth of lesions of Phytophthora cinnamomi in stems and roots of jarrah (Eucalyptus marginata) in relation to rainfall and stand density in Mediterranean forest of Western Australia. Can J For Res 25:961-969.

Burgess TI, Webster JL, Ciampini JA, White D, Hardy GEStJ, Stukely MJC (2009) Re-evaluation of Phytophthora species isolated during 30 years of vegetation health surveys in Western Australia using molecular techniques. Plant Dis 93:215-223.

Cahill DM, Rookes JE, Wilson BA, Gibson L McDougall KL (2008) Phytophthora cinnamomi and Australia's biodiversity: impacts, predictions and progress towards control. Aust J Bot 56:279-310.

CALM (2003) Phytophthora cinnamomi and disease caused by it. Volume 1 - Management Guidelines. Department of Conservation and Land management, Perth, Western Australia.

Collins BR, Parke JL, Lachenbruch B, Hansen EM, (2009) The effects of Phytophthora ramorum infection on hydraulic conductivity and tylosis formation in tanoak sapwood. Can J For Res 39: 1766-1776.

Davison EM (2011) How do Phytophthora de Bary kill trees? NZ J For Sci 41S:S25-S37.

Davison EM, Stukely MJC, Crane CE, Tay FCS (1994) Invasion of phloem and xylem of woody stems and roots of Eucalyptus marginata and Pinus radiate by Phytophthora cinnamomi. Phytopathology 84:335-340.

Davison EM, Tay FCS (1987) The effect of waterlogging on infection of Eucalyptus marginata seedlings by Phytophthora cinnamomi. New Phytol 105:585-594.

Drew MC (1997) Oxygen deficiency and root metabolism: injury and acclimation under hypxia and anoxia. Ann Rev Plant Physiol and Plant Mol Biol 48:223-250.

Gisi U, Zentmyer GA, Klure L (1980). Production of sporangia by Phytophthora cinnamomi and $P$. palmivora in soils at different matric potentials. Phytopathology 70:301-306.

Greslebin AG, Hansen EM (2010) Pathogenicity of Phytophthora austrocedrae on Austrocedrus chilensis and it relation with mal del ciprés in Patagonia. Plant Pathol 59: 604-612.

Hüberli D, Hardy GEStJ, White D, Williams N, Burgess TI (2013) Fishing for Phytophthora from Western Australia's waterways: a distribution and diversity survey. Australas Plant Pathol 42:251-260.

Hüberli D, Tommerup IC, Colquhoun IJ, Hardy GEStJ (2002) Evaluation of resistance to Phytophthora cinnamomi in seed-grown trees and clonal lines of Eucalyptus marginata inoculated in lateral branches and roots. Plant Pathol 51:435-442.

Jung T, Stukely MJC, Hardy GEStJ, White D, Paap T, Dunstan WA, Burgess TI (2011) Multiple new Phytophthora species from ITS Clade 6 associated with natural ecosystems in Australia: evolutionary and ecological implications. Persoonia 26:13-39.

McCreadie TA, Dixon KW, Sivasithamparam K (1985) Variability in the resistance of Banksia L.f. species to Phytophthora cinnamomi Rands. Aust J Bot 33:629-637.

MacDonald JD, Duniway JM (1978) Influence of matric potential and osmotic components of water potential on zoospore discharge in Phytophthora. Phytopathology 68: 751-755. 
McDougall KL, Hobbs RJ, Hardy GEStJ (2002) Vegetation of Phytophthora cinnamomi-infested and adjoining uninfested sites in the northern jarrah (Eucalyptus marginata) forest of Western Australia. Aust J Bot 50:277-288.

Newhook FJ, Young BR, Allen SD, Allen RN (1981). Zoospore motility of Phytophthora cinnamomi in particulate substrates. Phytopath Z 101:202-209.

Parke JL, Oh E, Voelker S, Hansen EM, Buckles G, Lachenbruch B (2007) Phytophthora ramorum colonizes tanoak xylem and is associated with reduced stem water transport. Phytopathology 97: 1558-1567.

Passioura JB (2012) Phenotyping for drought tolerance in grain crops: when is it useful to brrders? Functional Plant Biol 39:851-859.

Podger FD (1972) Phytophthora cinnamomi, a cause of lethal disease of dry sclerophyll Eucalyptus marginata Sm forests in Western Australia. Phytopathology 62:972-981.

Rea AJ, Burgess TI, Hardy GEStJ, Stukely MJC, Jung T (2011) Two novel and potentially endemic species of Phytophthora associated with episodic dieback of Kwongan vegetation in the south-west of Western Australia. Plant Pathol 60:1-14.

Scott PM, Burgess TI, Barber PA, Shearer BL, Stukely MJC, Hardy GEStJ, Jung T (2009) Phytophthora multivora sp. nov., a new species recovered from declining Eucalyptus, Banksia, Agonis and other plant species in Western Australia. Persoonia 22:1-13.

Shearer BL, Crane CE (2012) Phytophthora cinnamomi visible necrotic lesion-colonisation relationships in native flora. Australas Plant Pathol 41:633-644.

Shearer BL, Crane CE, Fairman RG, Dunne CP (2009) Ecosystem dynamics altered by pathogenmediated changes following invasion of Banksia woodland and Eucalyptus marginata forest biomes of south-western Australia by Phytophthora cinnamomi. Australas Plant Pathol 38:417-436.

Shearer BL, Crane CE, Dunne CP (2012) Variation in vegetation cover between shrubland, woodland and forest biomes invaded by Phytophthora cinnamomi. Australas Plant Pathol 41:413-424.

Smith BJ, Shearer BL, and Sivasithamparam K (1997) Compartmentalization of Phytophthora cinnamomi in stems of highly susceptible Banksia brownii treated with phosphonate. Mycol Res 101: 1101-1107.

Stukely MJC, Crane CE (1994) Genetically based resistance for Eucalyptus marginata to Phytophthora cinnamomi. Phytopathology 84:650-656.

Tippett JT, Shea SR, Hill TC, Shearer BL (1983) Development of lesions caused by Phytophthora cinnamomi in secondary phloem of Eucalyptus marginata. Aust J Bot 31:197-210.

Tynan KM, Scott ES, Sedgley M (1998) Development of excised shoot and root assays for in vitro evaluation of Banksia species for response to Phytophthora species. Plant Pathol 47:456462.

VSN International (2012) GenStat for Windows 15th Edition. VSN International, Hemel Hempstead, UK.

Wills RT (1992) The ecological impact of Phytophthora cinnamomi in the Stirling Range National Park, Western Australia. Aust J Bot 17:145-159. 


\section{Figures}

Fig. 1 Average invasion score for each Pathogen, Host and Season. Invasion scores: 0: not present in the sapwood, 1: present 0 to $5 \mathrm{~mm}$ into sapwood, 2: present 5 to $10 \mathrm{~mm}$ into sapwood, 3: present 10 to $15 \mathrm{~mm}$ into sapwood.

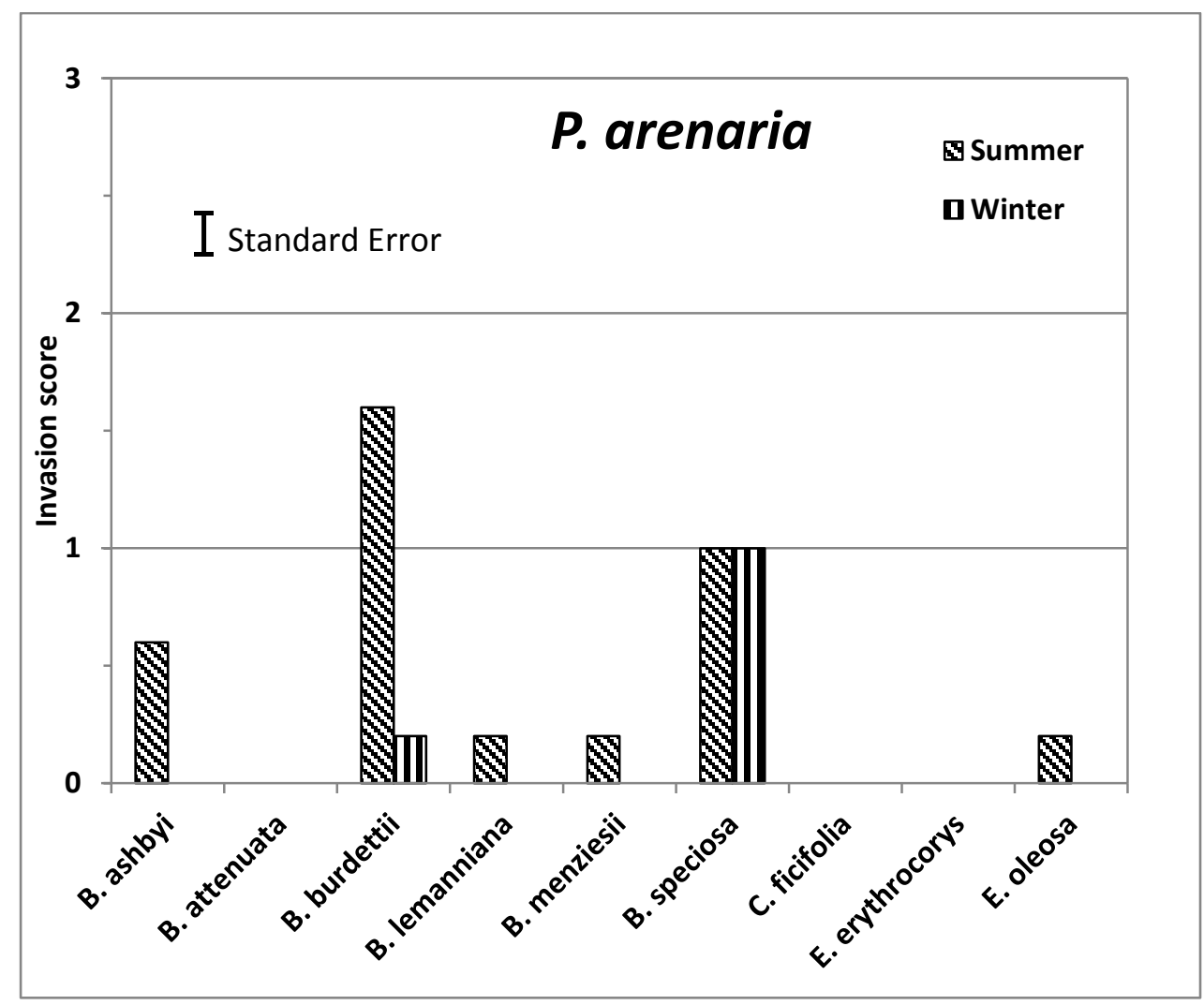



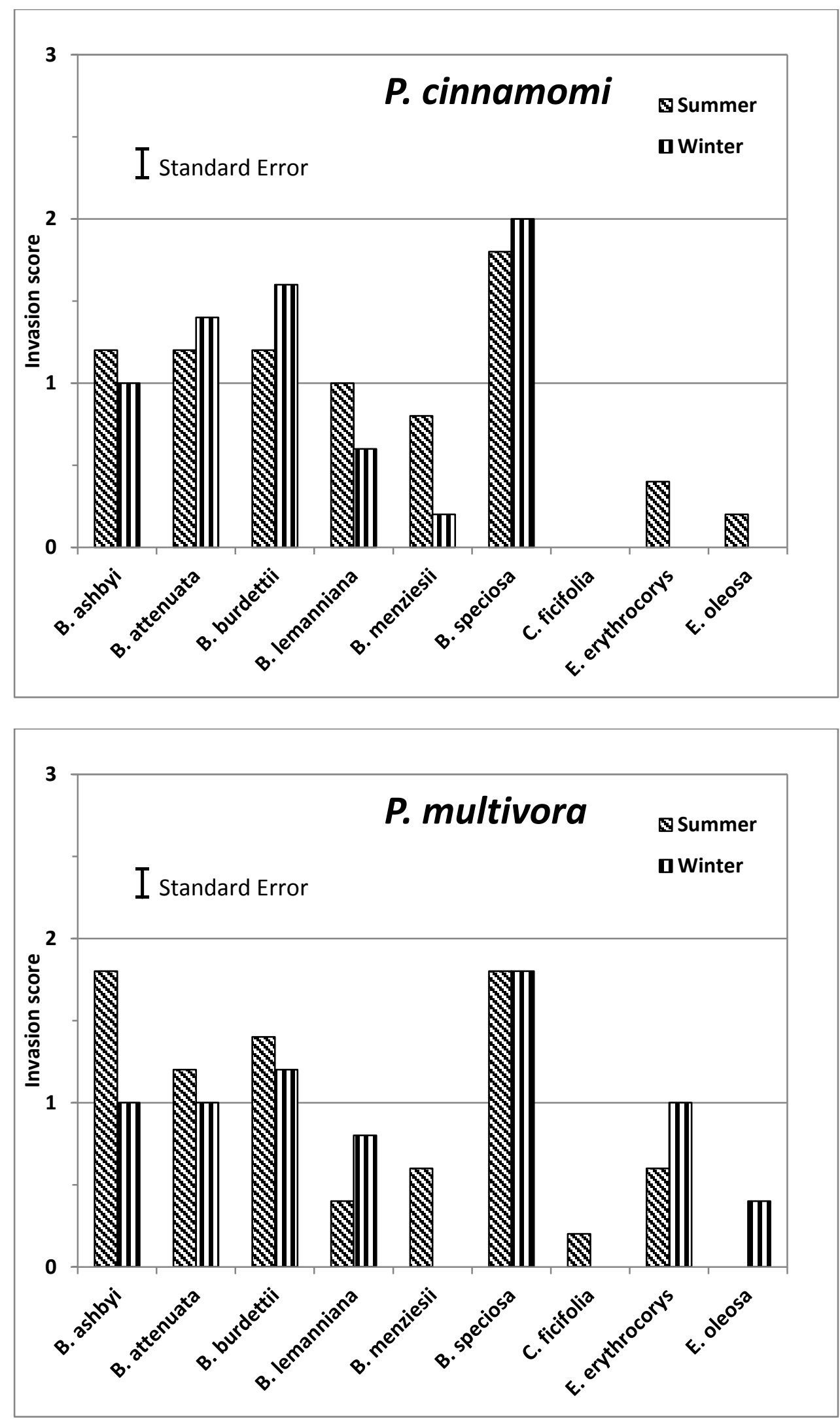
Fig 2. Hyphae of $P$. cinnamomi in ray cells of $B$. speciosa (2A) and xylem vessels of $B$. attenuata (2B), and hyphae of $P$. multivora in xylem vessels of $B$. speciosa (2C).

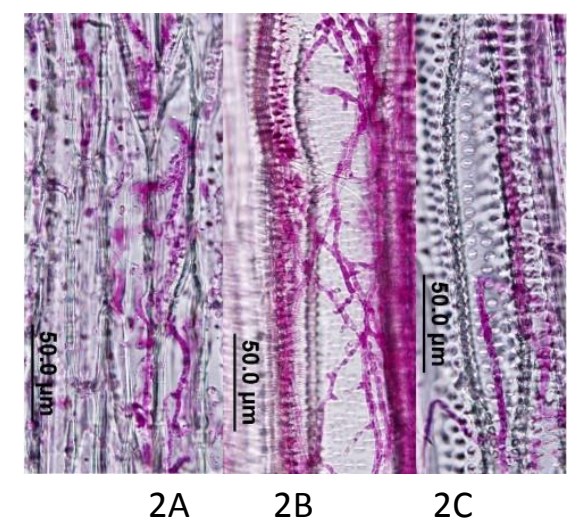

\section{Tables}

Table 1 Phytophthora isolates used in the inoculation experiments.

\begin{tabular}{|c|c|c|c|c|}
\hline Isolate & $\begin{array}{l}\text { Culture collection } \\
\text { number }{ }^{1}\end{array}$ & Isolated from: & $\begin{array}{l}\text { Date } \\
\text { isolated }\end{array}$ & GenBank number \\
\hline $\begin{array}{l}\text { P. arenaria } \\
\text { EB37 }\end{array}$ & WAC13674 & $\begin{array}{l}\text { Soil and roots, } \\
\text { Dandaragan, WA }\end{array}$ & 2012 & KJ463361 \\
\hline $\begin{array}{l}\text { P. cinnamomi } \\
\text { EB } 35\end{array}$ & WAC13692 & Gravel, Busselton, WA & 2011 & KJ463362 \\
\hline $\begin{array}{l}\text { P. multivora } \\
\text { EB25 }\end{array}$ & WAC13675 & $\begin{array}{l}\text { Soil and roots, } \\
\text { Dandaragan, WA }\end{array}$ & 2007 & KJ463363 \\
\hline
\end{tabular}

${ }^{1}$ Culture collection of the Department of Agriculture and Food Western Australia 
Table 2 Hosts used in the inoculation experiments

\begin{tabular}{lll}
\hline Host & Winter inoculation date & Summer inoculation date \\
\hline Banksia ashbyi & 21.6 .2012 & 4.4 .2013 \\
B. attenuata & 2.8 .2012 & 11.4 .2013 \\
B. burdettii & 5.7 .2012 & 28.32013 \\
B. lemanniana & 19.7 .2012 & 26.2 .2013 \\
B. menziesii & 9.8 .2012 & 6.3 .2013 \\
B. speciosa & 7.6 .2012 & 18.4 .2013 \\
Corymbia ficifolia $^{1}$ & 12.7 .2012 & 19.1 .2013 \\
Eucalyptus erythrocorys $_{\text {E. oleosa }}^{28.6 .2012}$ & 12.2 .2013 \\
In the context of this work, Corymbia is considered a eucalypt
\end{tabular}


Table 3 Significance of treatment effects on invasion into sapwood at the inoculation point.

\begin{tabular}{lll}
\hline Term & d.f. & Radial invasion at inoculation point \\
\hline + Banksia vs Eucalypt & 1 & $<.001$ \\
+ BanksiaHost & 5 & $<.001$ \\
+ EucalyptHost & 2 & 0.012 \\
+ Pathogen & 2 & $<.001$ \\
+ Season & 1 & $<.001$ \\
+ Banksia vs Eucalypt.Pathogen & 2 & $<.001$ \\
+ Pathogen.BanksiaHost & 10 & 0.001 \\
+ Pathogen.EucalyptHost & 4 & 0.028 \\
+ Banksia vs Eucalypt. Season & 1 & 0.039 \\
+ Season.BanksiaHost & 5 & 0.007 \\
+ Season.EucalyptHost & 2 & n.s. \\
+ Pathogen.Season & 2 & n.s. \\
+ Banksia vs Eucalypt.Pathogen.Season & 2 & n.s. \\
+ Pathogen.Season.BanksiaHost & 10 & $<.001$ \\
+ Pathogen.Season.EucalyptHost & 4 & n.s. \\
\hline
\end{tabular}


Table 4 Invasion scores for the different hosts in all seasons. Values within columns with the same superscript are not significantly different $(P=0.05)$.

\begin{tabular}{lll}
\hline Pathogen & All banksias & All eucalypts \\
\hline P. arenaria & $0.400^{\mathrm{a}}$ & $0.033^{\mathrm{a}}$ \\
P. cinnamomi & $1.167^{\mathrm{b}}$ & $0.100^{\mathrm{a}}$ \\
P. multivora & $1.083^{\mathrm{b}}$ & $0.367^{\mathrm{a}}$ \\
LSD & 0.240 & 0.612 \\
\hline
\end{tabular}


Table 5 Sample size required for detecting differences at $\mathrm{P}=5 \%$.

\begin{tabular}{llll}
\hline Size of difference detected & \multicolumn{3}{l}{ Probability of detection (\%) } \\
& 60 & 70 & 80 \\
\hline 0.4 & 10 & 13 & 16 \\
0.5 & 7 & 9 & 11 \\
0.6 & 5 & 6 & 8 \\
\hline
\end{tabular}

